\title{
A new fifteenth-to-sixteenth-century pottery kiln on the Tagus basin, Portugal
}

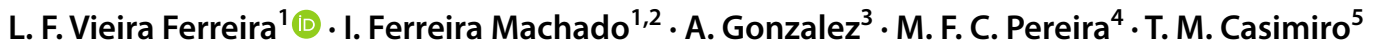

Received: 7 June 2018 / Accepted: 17 October 2018 / Published online: 24 October 2018

(c) Springer-Verlag GmbH Germany, part of Springer Nature 2018

\begin{abstract}
A detailed archaeometric study of pottery was made of a fifteenth-to-sixteenth-century kiln located inside the walls of the Castle of Alenquer. The locally collected sherds are lead glazed, and mostly exhibit a green or dark yellow decoration. Only in one case, a fragment of a bowl, tin oxide was detected in the white glaze. Pastes from the ceramics of the Alenquer kiln were spectroscopically characterized in terms of their mineralogical and elemental composition. This pottery was fired twice, the first time at high temperatures to produce the biscotto, and the second time at lower temperatures to glaze the ceramics. Although only one type of raw material collected locally was used, two types of ceramic pastes were detected and organized into two groups: one produced at about $850^{\circ} \mathrm{C}$ and another at about $950^{\circ} \mathrm{C}$. Pastes from Group 1 were converted into Group 2 pastes whenever the temperature of the kiln was raised from 850 to $950{ }^{\circ} \mathrm{C}$, as confirmed by firing Group 1 pastes in an oven. These results were compared with those obtained for coeval ceramics, namely at Santo António da Charneca and Mata da Machada. Both kilns were located on the south shore of the river Tagus (Lisbon), as previously reported.
\end{abstract}

Graphical abstract The first archaeometric study of ceramics produced in the kiln of Alenquer, (Portugal, fifteenth to sixteenth centuries) is reported, with the use of surface spectroscopies techniques, namely micro-Raman. Significant differences were found from two coeval kilns also located at the Tagus basin, Santo António da Charneca and Mata da Machada.

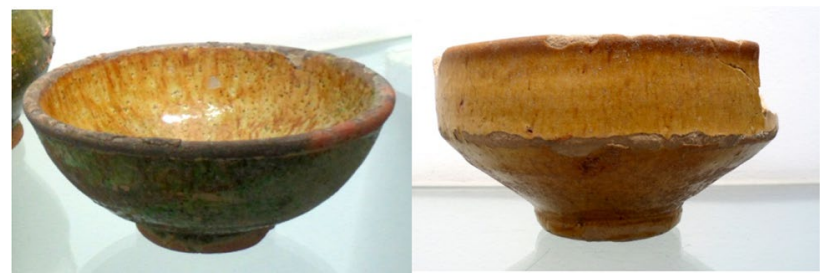

L. F. Vieira Ferreira

lfvieiraferreira@tecnico.ulisboa.pt

1 CQFM-Centro de Química-Física Molecular and IN-Institute for Nanosciences and Nanotechnologies and IBB-Institute for Bioengineering and Biosciences, Instituto Superior Técnico, Universidade de Lisboa, 1049-001 Lisbon, Portugal

2 Polytechnic Institute of Portalegre, 7300-110 Portalegre, Portugal

3 ARQA, Associação de Arqueologia da Amadora, Rua Mouzinho de Albuquerque 21 r/c Esq ${ }^{\circ}$, Damaia, 2720-389 Amadora, Portugal
4 CERENA-Centro de Estudos em Recursos Naturais e Ambiente, Instituto Superior Técnico, Universidade de Lisboa, Av. Rovisco Pais, 1049-001 Lisbon, Portugal

5 Instituto de História Contemporânea e Instituto de Arqueologia e Paleociências da, Departamento de História, Universidade Nova de Lisboa, Avenida de Berna 26-C, 1069-061 Lisbon, Portugal 


\section{Introduction}

The town of Alenquer is located approximately $50 \mathrm{~km}$ north of Lisbon and about $8.5 \mathrm{~km}$ from the Tagus river, in the West Region of Portugal.

In a recent paper, Cardoso and others reported the discovery of the remains of a ceramic kiln located inside the walls of the castle of Alenquer [1]. The type of objects permitted to conclude that this pottery was being manufactured somewhere between late-fifteenth or mid-sixteenth century although there is documental evidence that pottery production was happening inside the castle in as earlier as the thirteenth century with the reference to pottery kilns in the city's charter [1]. This city is located within the hydrographic basin of the Tagus, where two other coeval ceramic kilns had also been found and reported [2-6], both south of Lisbon near the city of Barreiro.

Those two other kilns are known to have produced tinglazed wares in Portugal from the late-fifteenth century to the early-sixteenth century [2-6]: the Mata da Machada (MM) kiln, reported to be active between about 1480 to 1530 [4]; and the Santo António da Charneca (SAC) kiln $[5,6]$. The first Hispano-Moresque tiles produced in Portuguese kilns were found at SAC, in a pit used for rejected pottery. An archaeometric study of these tiles, and a comparison with those produced in Seville, Spain, was published by our group [2].

There is an ongoing discussion in archaeological literature about the importance of such production areas in the Tagus valley. Although their major purpose may have been a local or regional supply, these workshops were also sending ceramic cargos on board ships towards Portuguese colonies [7]. On a regional basis, objects with similar characteristics with the Alenquer productions have been found in Cascais and Lisbon [1]. Their location close to the Tagus River, a natural trade route, may, in fact, support the idea that these were producing for a wider consumer base.

The type of wares associated with this collection ranges from what can be considered everyday objects such tableware with bowls and plates and even cooking pots and other more ludic objects such as whistles with animal forms such as horses. Green, light and dark yellow lead-glazed ceramics were the mains objects used at the table of Portuguese populations in the late fifteenth until the mid-sixteenth century with a high number of potters, known as malagueiros de amarelo e verde involved in the production [8]. In the second half of the sixteenth century, white tin-glazed wares tend to become more numerous although yellow and green glazed continue to be found in domestic environments.

Although this paper does not include non-glazed courseware, the Alenquer workshop associated with the kiln discovered inside the castle was also producing a wide variety of courseware vessels used in different domestic activities.

The subsequent growth and expansion of the Lisbon ceramic workshops in the seventeenth century is well documented [3], supporting the existence of tin-glaze ceramic production in Santos-o-Velho in the city, at least from 1561 onwards [9], although its inception can be traced back to at least the early sixteenth century [3,9-11].

In this study, our main goal is to first ever to attempt the spectroscopic characterization of pigments, glazes and pastes of the ceramics produced in the kiln of Alenquer [1]. Samples were studied with the use of non-invasive or quasinon-invasive techniques, namely X-ray diffraction (XRD), micro-Raman, and $\mathrm{X}$-ray fluorescence emission (XRF) as our three main analytical tools. Ground-state diffuse reflectance (GSDR) was also used here. A comparison with SAC and MM pottery was made as well with the purpose of understanding if this production had any relation with the other known contemporary kilns in the Tagus valley area.

Raw materials (clays) were collected locally, including on the hill where stands the castle of Alenquer, at different levels from the top to the bottom of the hillside. The mineralogical content of the samples was evaluated-when collected and after firing at $950{ }^{\circ} \mathrm{C}$ in an electric furnace for 12 and $36 \mathrm{~h}$-followed by a 4-h cooling phase for the slow return to room temperature. These results were compared with both the mineralogical composition and the elemental compositions of the ceramic sherds' pastes under study.

\section{Experimental}

\subsection{Materials studied}

The experimental results presented here are for nine pottery sherds with different glazes and forms, shown in Fig. 1, and were selected from a universe of 18 all of them analysed in this work. Many other sherds were recovered from the openair stockpiles located on the west hillside of the Alenquer castle, where the rejected pottery from the pottery workshop was dumped, and in exhibition at the local museum. a1-a3 are dark yellow glazed sherds; a4 and a5 are dark brown sherds; a6-a9 are green and white, or green, or green and yellow sherds. Their dimensions are of about $7 \mathrm{~cm} \times 7 \mathrm{~cm}$ in most cases.

The selected sherds, corresponding to different shapes, were considered to be representative of Alenquer's kiln.

The geology of the Alenquer municipality is divided into three important morphological zones [12-14]: the eastern plain alluvial area of the Tagus (Miocene to present), a Paleogenic central zone, and a western zone where an extensive massif of Jurassic formations predominates. The mineral 
Fig. 1 Representative sherds from the Alenquer kiln. a1-a3 Dark yellow glaze; $\mathbf{a 4 , ~ a 5 ~ d a r k ~}$ brown and dark yellow/dark brown glaze; a6 bowl, green outside and white inside; $\mathbf{a 7 ,}$ a8 green glaze; $\mathbf{a 9}$ green and yellow glaze. a10-a12 Examples of coeval pottery

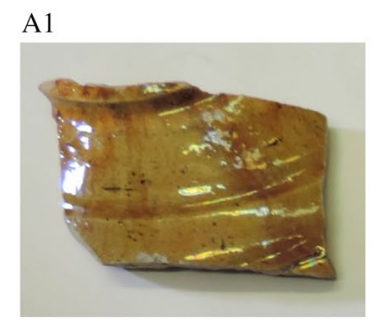

A2

A3

$$
\text { A4 }
$$

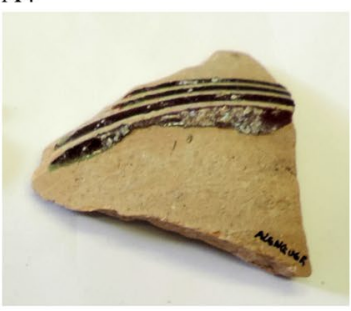

A7
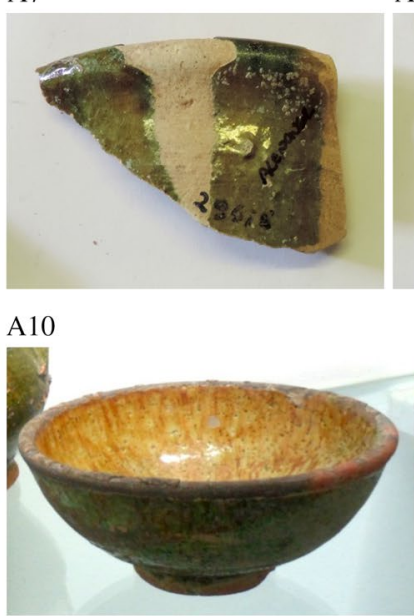

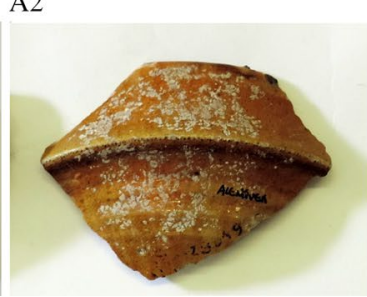

A5

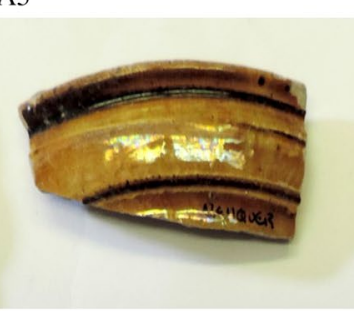

A8

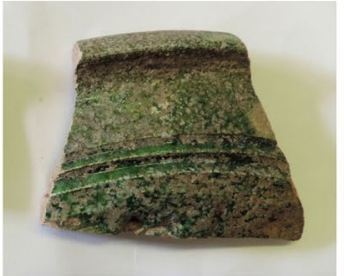

A11

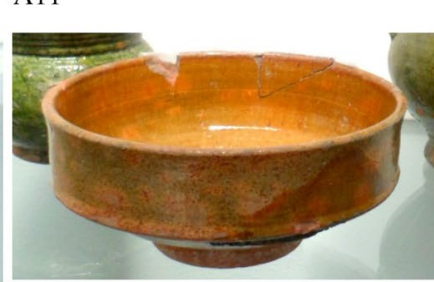

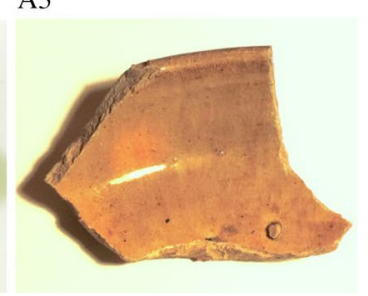

A6

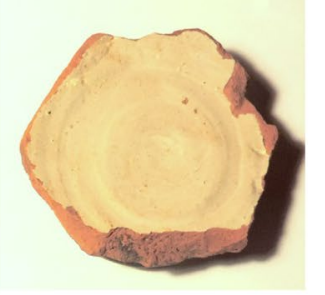

A9

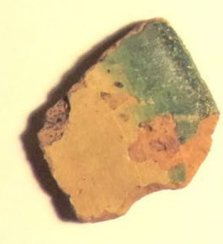

A12 resources are diversified, including building materials, fossil fuels, kaolin, salt rock, gypsum and mineral waters. Clays and marls have been used in the manufacture of ceramics.

The Alenquer Castle was implanted in the "Ota, Alenquer e Silveira carbonated formations" (included in the Jurassic $\mathrm{J}^{4}$ Kimmeridgian). This formation contains mainly carbonate and siliciclastic rocks. Outcrops from the vicinity of Alenquer city (Barranco da Nascente and Vale da Ribeira) show the presence of different types of marls and clays with low carbonate content [12-14].

In the surrounding area, other sources of clay and marl resources could be considered: the "Cheganças Complex", including different types of clays and marls, intercalated with limestones and sandstones; and the Miocene complex (Helvetian and Burdigalian) where sandy clays with low carbonate content are common [12-14].

Due to proximity, clay samples were collected very close to the dump ceramic area, at different levels of the Castle of Alenquer western hillside (Jurassic $\mathrm{J}^{4}$ formation). The inclusion of these samples in this study serves to confirm if the material used in the production of the ceramics was extracted in the area of the castle.

\subsection{Spectroscopic techniques under use}

The Raman microspectroscopy, XRF, XRD and ground-state diffuse reflectance absorption equipment used in this work are described below.

\subsubsection{Raman microspectrometry setup}

Micro-Raman measurements were carried out in a back-scattering micro-configuration, with a Renishaw InVia confocal Raman microscope, using a $532 \mathrm{~nm}$ excitation and $100 \times$, $50 \times, 20 \times, 10 \times$ and $5 \times$ objectives. The spectral resolution of the Raman spectrometer was $\sim 1 \mathrm{~cm}^{-1}$. All Raman spectra were recorded at least 5 times for each sample in different locations, and all spectra presented in this paper are representative. 
Data acquisition was performed with the Renishaw software Wire 4 and data processing, namely the baseline correction was done when needed, with the Wire 4 software or with the LabSpec software from Jobin Yvon. Ceramic bodies (pastes) were analyzed either from a recently scraped surface of the sherds or from ground sherd fragments (10-20 mg). Further details about the use of this spectroscopic tool for the study of ancient Portuguese ceramics can be found in references [15-19].

\subsubsection{X-ray fluorescence experiments}

The chemical composition of ceramic glazes and pastes was also accurately determined by X-ray fluorescence with the use of a Niton XL3T GOLDD from Thermo Scientific spectrometer with X-ray generator of $50 \mathrm{kV} / 200 \mu \mathrm{A}$, equipped with a CCD for image location ( $3 \mathrm{~mm}$ spot diameter) and storage. Other details for the data acquisition and treatment can be found in references [16-19].

\subsubsection{X-ray diffraction experiments}

The identification of the ceramic body powder crystalline phases was carried out using an X-ray diffractometer at CERENA (Panalytical X'PERT PRO model), with CuK $\alpha$ radiation. The measurement parameters used were $2 \theta$ $\left(5^{\circ}-65^{\circ}\right)$; step size $2 \theta=0.033^{\circ}$ and a scan step time of $80 \mathrm{~s}$ with generator settings of $35 \mathrm{~mA}$ and $40 \mathrm{kV}$.

In the case of XRD measurements, only about $10 \mathrm{mg}$ of powder sample is needed to perform an experiment, so it can be considered a quasi-non-invasive technique.

\subsubsection{Ground-state diffuse reflectance absorption spectra (GSDR)}

The setup for ground-state absorption experiments as well as the needed calculations are described in detail in [20].

\subsection{General}

In regard to the heating procedure of the collected clay samples ( $\mathrm{J}^{4}$-Jurassic formation) at laboratory level, all samples were placed in porcelain crucibles and submitted to a heat treatment in a high-temperature chamber electric furnace (Nabertherm, Germany), in a range $600-950{ }^{\circ} \mathrm{C}$ from 8 up to $36 \mathrm{~h}$, with a heating rate of about $5{ }^{\circ} \mathrm{C} / \mathrm{min}$, and were allowed to return to room temperature at identical rate.

Micro-Raman studies were in most cases made with the use of a 50x-long working distance objective and a high-definition colour camera. The Renishaw equipment has accurate confocal capabilities, enabling in-depth studies from the surface to about $150 \mu \mathrm{m}$. For XRF, the estimated penetration depth is about $30 \mu \mathrm{m}$.

\section{Results and discussion}

\subsection{XRD studies}

The use of the XRD technique provided very useful information regarding the mineralogical composition of the 18 samples studied in this work. The first point to be stressed is the non-Pliocene type of all samples under study [12-14], establishing immediately a sharp difference relative to most samples from MM, and all samples from SAC. In the productions from these coeval kilns, very low carbonate Pliocene materials were used in most cases $[2,18]$.

The results obtained are summarized in Fig. 2, where we present two types of ceramic bodies which we will designate from now on by Group 1 pastes and Group 2 pastes.

Group 1 is characterized by the existence of quartz $\left(\mathrm{Q}, \mathrm{SiO}_{2}, 2 \theta=21.0,26.7,36.7,46.0,50.2,60.0\right)$, the major component, and the presence of muscovite $(\mathrm{M}$, $\left.\mathrm{KAl}_{2}\left(\mathrm{Si}_{3} \mathrm{Al}\right) \mathrm{O}_{10}(\mathrm{OH})_{2}, 2 \theta=8.8,17.8,19.8,26.7,45.3\right)$, some gehlenite $\left(\mathrm{G}, \mathrm{Ca}_{2} \mathrm{Al}(\mathrm{AlSi}) \mathrm{O}_{7}, 2 \theta=24.3,29.3,31.4\right.$, $37.2,44.5,52.2,61.3)$ and small amounts of anorthite (An, $\left.\mathrm{CaAl}_{2} \mathrm{Si}_{2} \mathrm{O}_{8}, 2 \theta=22,27.5,27.9\right)$, rutile $\left(\mathrm{R}, \mathrm{TiO}_{2}, 27.8\right.$, $36.1,41.3,54.3,69.1)$, and hematite $\left(\mathrm{H}, \mathrm{Fe}_{2} \mathrm{O}_{3}, 2 \theta=24.2\right.$, 33.2, 35.7, 40.9, 49.5, 54.1, 57.7). Five samples of Fig. 1 are from Group 1.

Group 2 presents several major differences, namely the absence of muscovite and a marked presence of anorthite. It also evidences the formation of diopside (D, $\mathrm{CaMgSi}_{2} \mathrm{O}_{6}, 2 \theta=29.9,30.5,31.0,35.1,35.7$ ), a calcium and magnesium silicate although some iron may replace the magnesium forming augite. The diffractograms do not allow us to differentiate between diopside and augite; henceforth, wherever diopside is mentioned, it may, in fact, be diopside/augite. Four samples of Fig. 1 are from group 2 .

Based on the information gathered so far, we could be led to imagine the existence of two clay sources in use at the Alenquer kiln, an improbable hypothesis. The use of a distant clay source and the transportation of the clay by animal-drawn carts would have meant an additional cost to potters to be avoided in the fifteenth and sixteenth centuries.

The existence of Muscovite in Group 1 and its absence in Group 2 led us to test the hypothesis of different kiln temperatures for firing the «biscotto» of the ceramics. It is well documented in the literature that Muscovite may only be found in ceramic pastes at firing temperatures below $850{ }^{\circ} \mathrm{C}[21,22]$.

Figure 3 summarizes the main findings obtained by the use of XRD experiments. About $500 \mathrm{mg}$ of powdered paste was removed from three sherds of Group 1 (three tests) 
Fig. 2 Representative XRD patterns for pastes from Alenquer sherds: (i) type 1 ; (ii) type 2. The XRD peaks are assigned to quartz $(\mathrm{Q})$, diopside $(\mathrm{D})$, gehlenite (G), anorthite (An), hematite $(\mathrm{H})$, and $\mathrm{M}$ (muscovite)

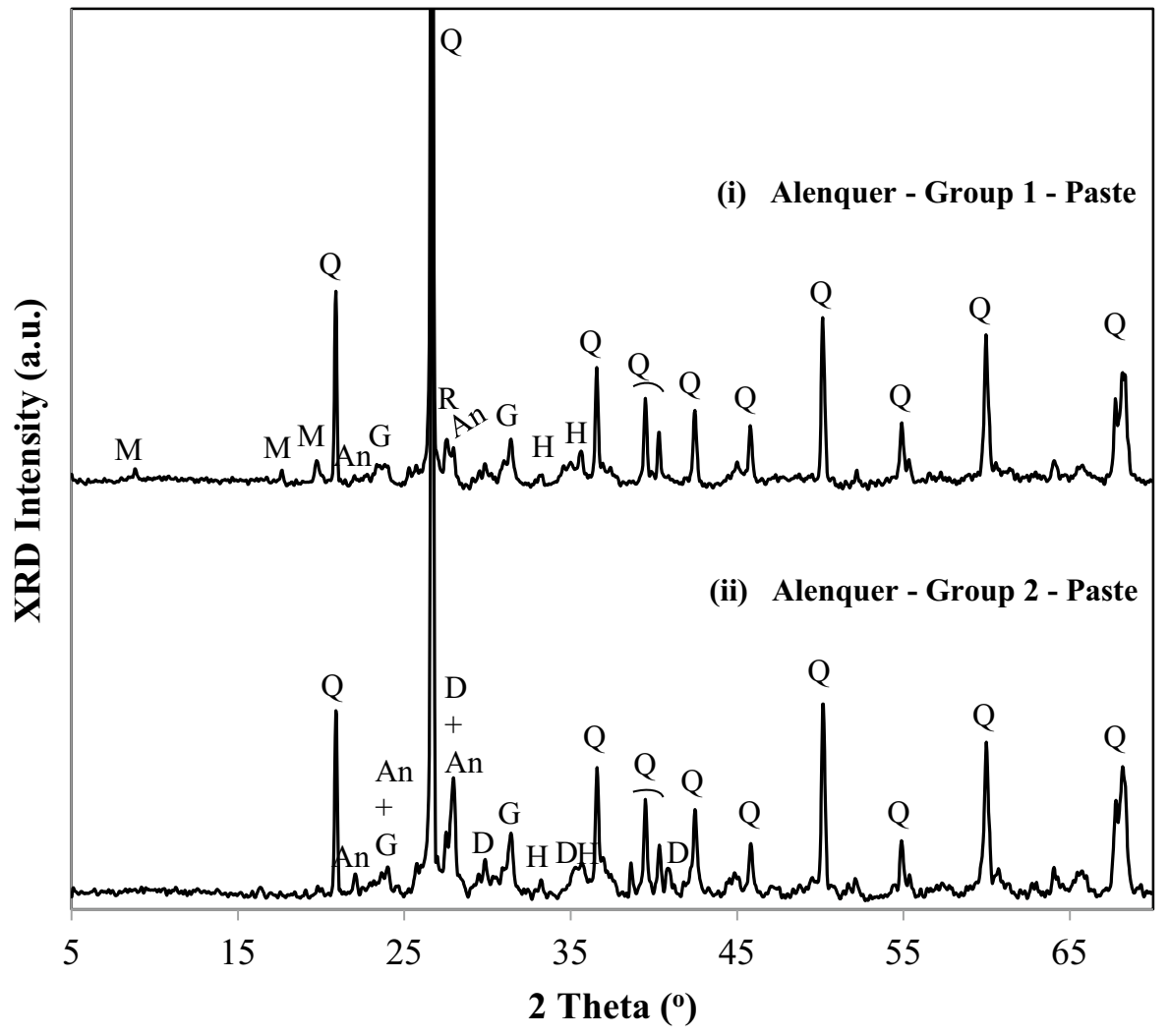

and fired in the electric furnace for $36 \mathrm{~h}$ at $950{ }^{\circ} \mathrm{C}$. This temperature was selected because it is described in the literature as allowing the formation of anorthite and diopside, however, without the formation of mullite [22-24], which is the case in curve (i).

Curve (ii) of Fig. 3 is the diffractogram of the powdered paste of one ceramic sherd belonging to Group 1 and curve (i) is the diffractogram of the same sample fired at $950{ }^{\circ} \mathrm{C}$ for $36 \mathrm{~h}$. As it can be seen, anorthite was formed in massive amounts while the peaks for muscovite and gehlenite disappeared. It can be concluded that in Group 1 sherds the temperature of the kiln did not exceed $850{ }^{\circ} \mathrm{C}$ and the difference for Group 2 was not caused by the use of a different raw material but rather of higher firing temperatures $\left(950{ }^{\circ} \mathrm{C}\right.$ for the pastes of Group 2).

Different kiln temperatures were used resulting in different mineral compositions of the ceramic bodies.

Curve (iv) of Fig. 3 presents the diffractogram of the raw materials collected by the authors on the hillside of Alenquer Castle. Muscovite, kaolinite $\left(\mathrm{K}, \mathrm{Al}_{2} \mathrm{Si}_{2} \mathrm{O}_{5}(\mathrm{OH})_{4}\right.$, $2 \theta=12.3,25,38.3,45.7$ and 55.4, $2 \theta=12.3,25,38.3,45.7$, 55.4), calcite $\left(\mathrm{CC}, \mathrm{CaCO}_{3}, 2 \theta=23,29.4,47.5\right)$, and rutile $\left(\mathrm{R}, \mathrm{TiO}_{2}, 27.8,36.1,41.3,54.3,69.1\right)$ were detected in the diffractogram, apart from the major component of the raw material which is quartz. By firing this clay at $950{ }^{\circ} \mathrm{C}$ during $8 \mathrm{~h}$ we could detect the formation of anorthite and also of some gehlenite and hematite, the latter due to the oxidative conditions of the furnace (curve (iii)). The composition of this fired clay approaches that of the pastes in Group 2, although the amount of anorthite is not as high as found in many Group 2 samples.

According to the XRD results, the pastes from Alenquer are quite different from the pastes produced near Lisbon region (SAC and MM). This fact clearly points to local origin of raw materials.

\subsection{XRF studies}

Ceramic bodies Table 1 presents the elemental chemical composition of the Alenquer ceramic pastes under study, obtained by XRF analysis, expressed as weight $\%$ of indicated oxides for major and minor elements, and parts per million (ppm) for trace elements. A global overview shows that the composition of the pastes is very uniform.

The major components of the ceramic bodies are silica and alumina and the data presented in Table 1 point to a typical value for ceramics produced using siliciclastic lowcarbonate raw materials, i.e. $70-80 \%$ in weight. The $\mathrm{CaO}$ content lies in the $\sim 8-15 \%$ range while the $\mathrm{K}_{2} \mathrm{O}$ content ranges from about 4 to $4.5 \%$. Clearly it is the amount of calcium in the raw material that plays an important role in the formation of minerals through firing the initial clay. It is well known that the formation of gehlenite implies the 
Fig. 3 Diffractograms for pastes of the ceramics and clays of Alenquer: (i) paste from Group 1 fired at $950{ }^{\circ} \mathrm{C}$; (ii) paste from Group 1; (iii) clay fired at $950{ }^{\circ} \mathrm{C}$; (iv) clay as collected from the castle hillside. The XRD peaks are assigned to quartz (Q), diopside (D), gehlenite (G), anorthite (An), rutile $(\mathrm{R})$, hematite $(\mathrm{H})$, and $\mathrm{M}$ (muscovite)

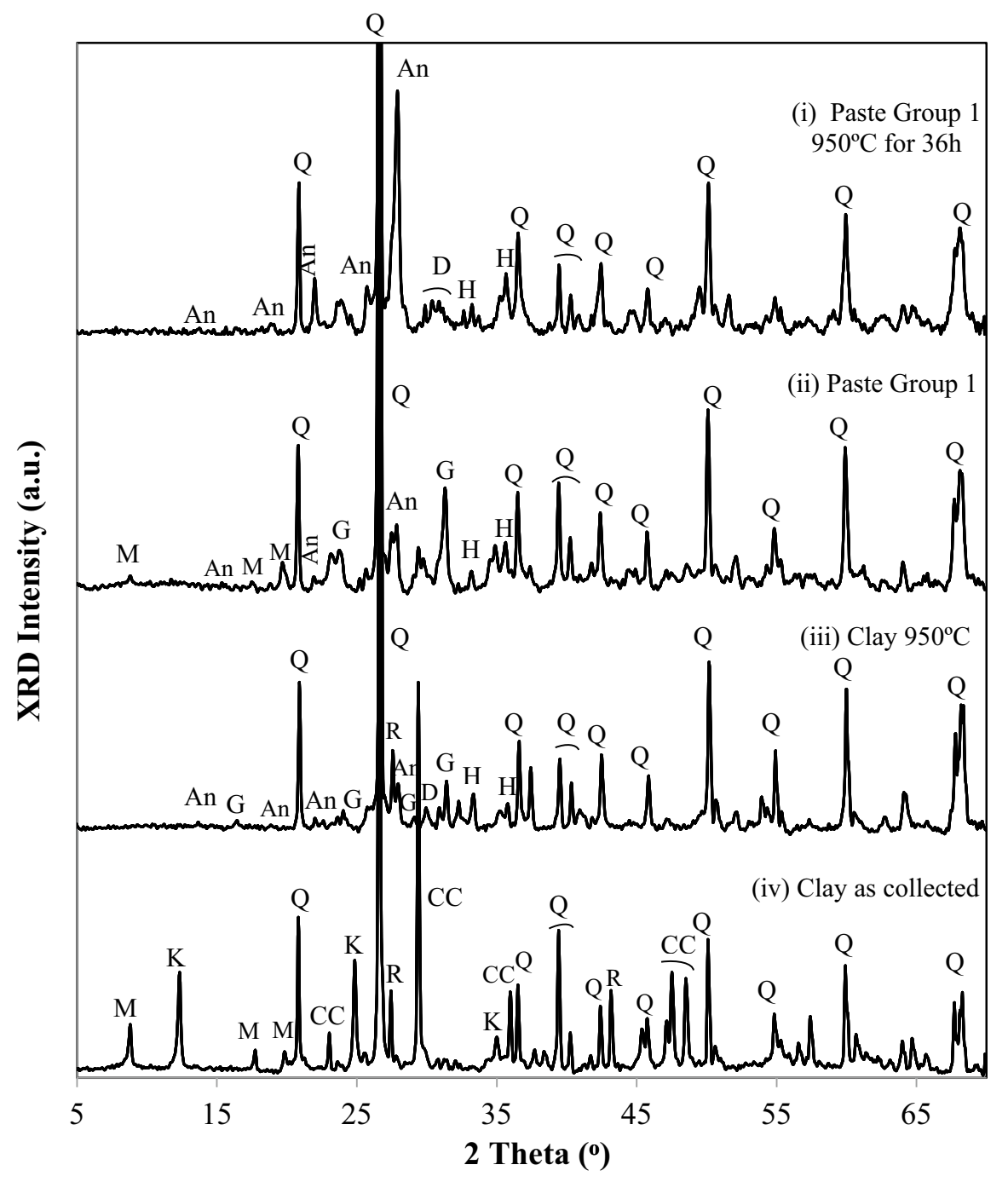

Table 1 Chemical composition of Alenquer sherds' pastes determined by the use of XRF, wt\% and ppm for traces elements

\begin{tabular}{|c|c|c|c|c|c|c|c|c|c|c|c|c|c|}
\hline Sherd & $\mathrm{MgO}$ & $\mathrm{Al}_{2} \mathrm{O}_{3}$ & $\mathrm{SiO}_{2}$ & $\mathrm{~K}_{2} \mathrm{O}$ & $\mathrm{CaO}$ & $\mathrm{TiO}_{2}$ & $\mathrm{Fe}_{2} \mathrm{O}_{3}$ & $\mathrm{Mn}$ & $\mathrm{Rb}$ & $\mathrm{Sr}$ & $\mathrm{Zr}$ & $\mathrm{Nb}$ & $\begin{array}{l}\left(\mathrm{SiO}_{2}+\mathrm{Al}_{2} \mathrm{O}_{3}+\mathrm{K}_{2} \mathrm{O}\right) / \\
\mathrm{CaO}\end{array}$ \\
\hline A1 & 1.6 & 17.2 & 60.3 & 4.4 & 10.3 & 1.4 & 4.7 & 217 & 86 & 89 & 150 & 20 & 8.0 \\
\hline A2 & 2.0 & 18.7 & 57.4 & 4.0 & 11.5 & 1.3 & 5.0 & 590 & 90 & 85 & 132 & 24 & 7.0 \\
\hline A 3 & 1.5 & 18.0 & 58.6 & 4.1 & 10.1 & 1.4 & 6.2 & 571 & 81 & 91 & 149 & 22 & 8.0 \\
\hline A4 & 1.3 & 17.8 & 60.1 & 4.4 & 9.7 & 1.6 & 5.1 & $\mathrm{nd} / \mathrm{nq}$ & 110 & 111 & 241 & 30 & 8.5 \\
\hline A5 & 1.3 & 18.0 & 60.4 & 4.2 & 10.1 & 1.4 & 4.5 & 293 & 92 & 92 & 160 & 21 & 8.2 \\
\hline A6 & 1.5 & 19.2 & 51.9 & 4.5 & 15.2 & 1.5 & 6.3 & 358 & 83 & 101 & 148 & 20 & 5.0 \\
\hline A7 & $\mathrm{nd} / \mathrm{nq}$ & 19.3 & 58.4 & 4.3 & 11.2 & 1.6 & 5.2 & 319 & 105 & 123 & 231 & 31 & 7.3 \\
\hline A8 & 1.5 & 20.9 & 56.8 & 4.4 & 9.9 & 1.6 & 4.8 & 439 & 106 & 108 & 214 & 25 & 8.3 \\
\hline A9 & 1.7 & 17.5 & 56.8 & 4.5 & 11.3 & 1.2 & 6.9 & 441 & 92 & 91 & 145 & 19 & 6.9 \\
\hline
\end{tabular}

$n d$ not detected, $n q$ not quantified

presence of twice more calcium carbonate when compared to calcium needed for anorthite formation [18, 19]. The ratio

$\mathrm{R}=\left(\mathrm{SiO}_{2}+\mathrm{Al}_{2} \mathrm{O}_{3}+\mathrm{K}_{2} \mathrm{O}\right) / \mathrm{CaO}$ may be used to evaluate the relative amounts of the structural and most abundant components of the ceramic pastes, the components related to detrital/siliciclastic minerals 
$\left(\mathrm{SiO}_{2}+\mathrm{Al}_{2} \mathrm{O}_{3}+\mathrm{K}_{2} \mathrm{O}\right)$ and the components related to chemi$\mathrm{cal} / \mathrm{biochemical}$ soluble fractions $(\mathrm{CaO})$. Quartz, alkaline feldspars, micas and clay minerals are the most typical minerals for the first group while the carbonate minerals are the most representative of the second group. Therefore, we will use it, in a double geological/ceramic sense, to compare the different clay materials and pastes.

This ratio $R$ lies in a very narrow band for the Alenquer ceramics' pastes, as one can see in Table $1, R \sim 5-9$.

Figure 4 presents a scatter plot of $\mathrm{K} / \mathrm{Si}$ versus $\mathrm{Ca} / \mathrm{Si}(\% \mathrm{wt}$ ratio) for all the 18 sherds studied here as well as for three fired clays, all from Alenquer. The XRF values measured for

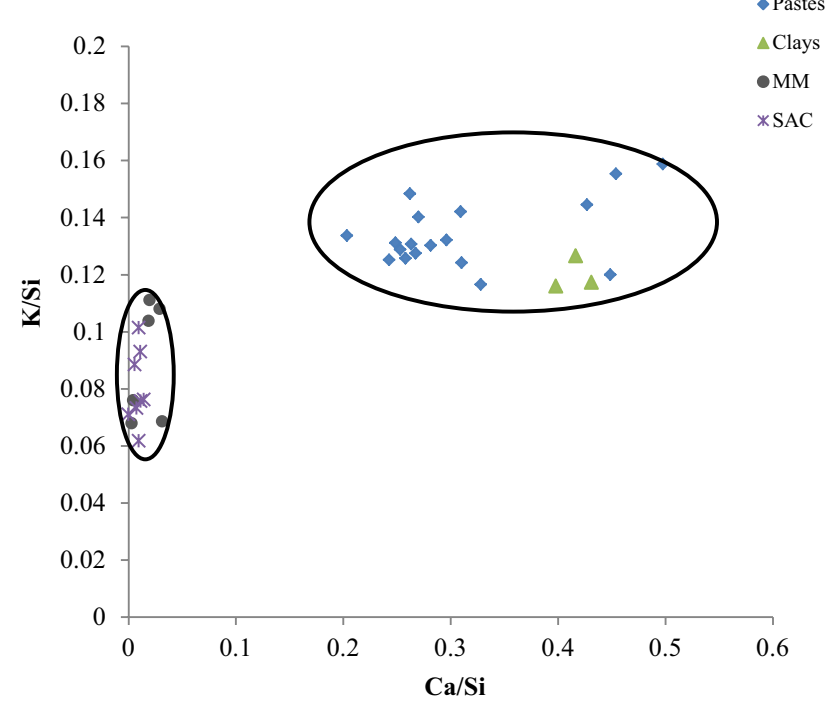

Fig. 4 Scatterplot of $\mathrm{K} / \mathrm{Si}$ versus $\mathrm{Ca} / \mathrm{Si}$ count ratios for the pastes and clays of Alenquer sherds. The counts measured by XRF for each element were normalized by $\mathrm{Si}$, considered as the main component of the ceramic body, to eliminate errors resulting from empirical measurements and data treatment procedures. SAC and MM data points from reference [18] each element were normalized by the Si content, the main component of the body of the ceramics, in this way eliminating errors from empirical measurements and data treatment procedures [25].

The fact that all the data points lie inside the small ellipse of Fig. 4, well separated from the ellipse containing the SAC and MM data took from reference [18], suggests again to a unique clay source as previously concluded from the diffractograms presents in Sect. 3.1.

The red colour of pastes is often due to the presence of iron in the original earthen clays used as raw materials; it appears in the form of hematite formed during the firing process in oxidizing conditions [26].

As concluded by the XRD results, the chemical data of Alenquer's pastes point out to a local supply of raw materials. Both results indicate that the local source is more aluminous (muscovite rich) and in an intermediate carbonate composition relative to Lisbon and SAC and MM production centres [18]. Given these considerations and conclusions of the experimental work performed for the clay gathered in the castle hill, it can be a potential source of supply for the raw materials for the ceramics found there. The stratigraphic record of Jurassic formations in the vicinity of the city of Alenquer also shows the occurrence of formations with the characteristics described previously which makes this hypothesis very plausible.

Glazes The elemental chemical composition of the coloured glazes (green, amber, dark brown, and white) obtained by XRF analysis is presented in Table 2 for the Alenquer samples under study.

The analysis of all samples shows that the two major components of the glazes are $\mathrm{SiO}_{2}$ and $\mathrm{PbO}$ resulting in ca $50-60 \%$ of the overall glaze composition. This points to a lead-based glaze in all productions. Without the presence of $\mathrm{SO}_{3}$, this percentage in weight reaches up to $78-80 \%$ of the glaze. Only one sherd (A6) has significant content of

Table 2 Chemical composition of Alenquer sherds' glazes determined by the use of XRF, wt $\%$

\begin{tabular}{|c|c|c|c|c|c|c|c|c|c|c|c|c|c|c|c|c|}
\hline & Colours & $\mathrm{MgO}$ & $\mathrm{Al}_{2} \mathrm{O}_{3}$ & $\mathrm{SiO}_{2}$ & $\mathrm{SO}_{3}$ & $\mathrm{~K}_{2} \mathrm{O}$ & $\mathrm{CaO}$ & $\mathrm{TiO}_{2}$ & $\mathrm{MnO}$ & $\mathrm{Fe}_{2} \mathrm{O}_{3}$ & $\mathrm{NiO}$ & $\mathrm{CuO}$ & $\mathrm{ZnO}$ & $\mathrm{As}_{2} \mathrm{O}_{3}$ & $\mathrm{SnO}_{2}$ & $\mathrm{PbO}$ \\
\hline A1 & Amber & $\mathrm{nd} / \mathrm{nq}$ & 4.3 & 17.5 & 34.8 & 0.3 & 0.7 & 0.0 & 0.2 & 2.8 & 0.0 & 0.1 & 0.0 & 4.1 & 0.2 & 34.9 \\
\hline A2 & Amber & $\mathrm{nd} / \mathrm{nq}$ & 4.2 & 16.3 & 31.1 & 0.3 & 1.1 & 0.1 & 0.2 & 3.6 & $\mathrm{nd} / \mathrm{nq}$ & 0.1 & 0.0 & 4.6 & 0.0 & 38.3 \\
\hline A3 & Amber & 1.8 & 6.6 & 20.1 & 32.5 & 0.4 & 0.9 & 0.1 & 0.2 & 2.8 & 0.0 & 0.1 & 0.0 & 3.2 & 0.1 & 31.2 \\
\hline A4 & Brown & $\mathrm{nd} / \mathrm{nq}$ & 5.3 & 26.8 & 28.6 & 2.4 & 3.1 & 0.3 & 0.2 & 1.9 & $\mathrm{nd} / \mathrm{nq}$ & 2.0 & 0.1 & 2.5 & 0.2 & 26.7 \\
\hline \multirow[t]{2}{*}{ A5 } & Amber & $\mathrm{nd} / \mathrm{nq}$ & 4.6 & 18.5 & 35.0 & 0.3 & 0.7 & 0.0 & 0.2 & 2.6 & 0.1 & 0.1 & 0.0 & 3.7 & 0.2 & 34.1 \\
\hline & Brown & $\mathrm{nd} / \mathrm{nq}$ & 5.3 & 23.1 & 26.1 & 0.8 & 1.5 & 0.1 & 0.2 & 2.8 & 0.1 & 0.1 & 0.0 & 3.3 & 0.2 & 36.5 \\
\hline A6 & Whitish & $\mathrm{nd} / \mathrm{nq}$ & 4.3 & 26.7 & 27.7 & 0.7 & 0.6 & 0.1 & 0.2 & 0.4 & 0.0 & 0.0 & 1.2 & 3.0 & 7.4 & 27.8 \\
\hline A7 & Green & $\mathrm{nd} / \mathrm{nq}$ & 5.1 & 24.2 & 33.1 & 1.2 & 2.6 & 0.1 & 0.2 & 1.5 & 0.0 & 2.4 & 0.0 & 3.1 & 0.1 & 26.1 \\
\hline A8 & Green & 2.0 & 6.5 & 24.4 & 29.8 & 0.7 & 3.5 & 0.2 & 0.2 & 1.0 & 0.1 & 1.7 & 0.0 & 2.7 & 0.1 & 26.9 \\
\hline \multirow[t]{2}{*}{ A9 } & Yellowish & $\mathrm{nd} / \mathrm{nq}$ & 5.2 & 24.8 & 34.4 & 0.4 & 0.0 & 0.0 & 0.2 & 0.3 & 0.06 & 0.0 & 0.0 & 3.5 & 0.0 & 31.0 \\
\hline & Green & $\mathrm{nd} / \mathrm{nq}$ & 7.6 & 25.2 & 25.5 & 0.7 & 2.2 & 0.1 & 0.2 & 0.5 & 0.05 & 3.2 & 0.0 & 3.4 & 0.0 & 31.3 \\
\hline
\end{tabular}

$n d$ not detected, $n q$ not quantified 
tin oxide. Therefore, all the remaining sherds are transparently glazed.

Important initial information obtained from the use of Table 2 data is the very high amount of sulphur that exists in all samples $\left(\mathrm{SO}_{3} \mathrm{wt} \%\right.$ varies from about $\left.17-33 \%\right)$. This points to the use of Galena $(\mathrm{PbS})$ as the main source of lead for the glaze preparation [27, 28]. Galena is quite a common mineral in Portugal and certainly $\mathrm{PbO}$ was most likely obtained by heating in a kiln. If the reduction process is not effective, considerable amounts of sulphur may remain in the glaze of the ceramics.

Nevertheless, the significant amounts of sulphur could also be explained if plant ashes were used as source of alkalis in the glaze production or else they were brought in the shell hash found in the sands [29]. However, Table 2 does not present high alkali contents, pointing to the exclusion of this hypothesis.

In the dark yellow glaze, the chemical composition indicates higher amounts of iron when comparing it with the green or white glazes. The $\mathrm{Fe}_{2} \mathrm{O}_{3}$ content is ca. 2.6-3.7 wt $\%$ in all dark yellow samples from Alenquer. In association with $\mathrm{Fe}_{2} \mathrm{O}_{3}$, we also observe the presence of $\mathrm{MnO}$, although in a much lower content (about $0.2 \mathrm{wt} \%$ ).

If the sulphur is present, it is reported that the dark yellow colour is a result of the (ferri-sulphide chromophore) $\mathrm{Fe}(\mathrm{III})-\mathrm{SO}_{3}$ chromophore [29-32]. Ground-state absorption spectra shown later will show this complex absorption peaking at $\sim 410-420 \mathrm{~nm}$, while Raman spectra do not identify this chromophore. Dark brown glazes show similar concentrations of manganese and iron, which led us to consider that the dark brown colour is simply due to a higher accumulation of the initial glazing slurry. The exception in Table 2 is sample A4, where a higher percentage of $\mathrm{CuO}$ was found, contrary to all the other samples where it does not exceed $0.1-0.2 \mathrm{wt} \%$.

The green colour of lead glazes is related to the presence of the $\mathrm{Cu}^{2+}$ ion, as one can see in Table $2(\mathrm{CuO}$ ca. 2.4-3.6 wt\%). The chromium content was lower than the detection limits of our XRF apparatus, excluding the use of chromium-based pigments to obtain the green colour [33]. Different copper salts were most probably used to produce this green coloration, the common one being basic copper acetate, although a mixture of yellow and blue pigments was also reported [33, 34].

In the white coloured glaze a high amount of tin oxide was found $\left(\mathrm{SnO}_{2}\right.$ ca. $\left.8 \%\right), \mathrm{SnO}_{2}$ being the third major component. The opacity of the white glazes-when compared to the other coloured glazes, green, dark yellow and brown-is due to the very high content of $\mathrm{SnO}_{2}$ in the white ones [35]. In coeval SAC and MM kilns' productions, $\mathrm{SnO}_{2}$ was already used as an opacifier agent for blue- or green-coloured glazes [2, 18]. However, Table 2 does not show this tendency neither for green nor for dark yellow glazes, both of which are transparent glazes.

\subsection{Raman microspectroscopic studies}

The micro-Raman spectroscopy was used to obtain information about the glazes and also about the ceramic bodies. This technique can be used to obtain additional information regarding the glazes, namely their crystalline or glassy structures. The latter are built from covalent bonds between the $\mathrm{SiO}_{4}$ tetrahedra in different modes. In regard to the glazes, the ratio of the stretching (i.e. $\sim 1000 \mathrm{~cm}^{-1}$ ) and bending $\left(\sim 500 \mathrm{~cm}^{-1}\right)$ Raman envelopes-measured as the band area ratio $\left(I_{\mathrm{p}}=A_{500} / A_{1000}\right)$, where $I_{\mathrm{p}}$ is the polymerization index proposed by Colomban [35-38] — can be correlated to the temperature of the kiln, the glaze composition and the different fluxing agents. Plots of $\nu_{\max }$ versus the wavenumber maximum $\left(\delta_{\max }\right)$ of bending Si-O multiplets $[38,39]$ allow one to identify glass types such as lead-based, soda or potash-based, mixed potash or soda-lime-based compositions.

Coloured glazes The micro-Raman spectra obtained for the different glazes (dark brown, dark yellow, white, yellow and green) from the Alenquer sherds are shown in Fig. 5(i)-(vi), while Fig. 6(i)-(vi) presents data for the ceramic pastes.

Curve (i) in Fig. 5 is from a dark brown glaze that was obtained at about $40 \mu \mathrm{m}$ depth using the confocal capabilities of our micro-Raman set-up. This sherd (A4) belongs to Group 2. Several peaks located at 323, 390, 495, 504, 633 , and $1008 \mathrm{~cm}^{-1}$ could be easily observed, part of them superimposed onto the bending band of the glaze $(\delta)$. A band peaking at $969 \mathrm{~cm}^{-1}$, the stretching band $(\nu)$ of $\mathrm{SiO}_{2}$, could also be observed, with a maximum of a typical lead-type glaze. The $145 \mathrm{~cm}^{-1}$ peak may be assigned to crystalline anatase, while the other peaks indicate the presence of diopside, as indicated by the use of the RRUFF database for minerals [40]. Diopside is a calcium and magnesium silicate often brown or brownish in colour [40]. However, it could only be detected at $40 \mu \mathrm{m}$ depth; therefore, its location lies at the interface between paste and the glaze.

Thus, diopside could indeed be the pigment responsible for the dark brown colour. However, one has to take into account the high level of iron and sulphur detected by the XRF experiments, and also the diffuse reflectance absorption spectra for the dark brown and amber glazes. These data point to $\mathrm{Fe}(\mathrm{III})-\mathrm{SO}_{3}$ chromophore $[30,32]$ as the basis of these colours in the two glazes.

Curve (ii) of Fig. 5 is representative of the dark yellow glazes. A sherd with this glaze (A3) belongs to Group 1. The Raman spectrum was obtained from the surface of the glaze and one can observe the bending and stretching Raman envelopes of the glaze, with maxima at 465 and $969 \mathrm{~cm}^{-1}$, respectively. No specific Raman signature for the dark 
Fig. 5 Micro-Raman spectra obtained for the glazes of Alenquer sherds. The Raman signals are assigned to quartz $(\mathrm{Q})$, anatase (A), diopside (D), $\mathrm{T}$ (tin oxide) and carbon black (CB). $\delta$ and $\nu$ identify the bending and stretching Raman envelopes of $\mathrm{SiO}_{2}$ vibrations

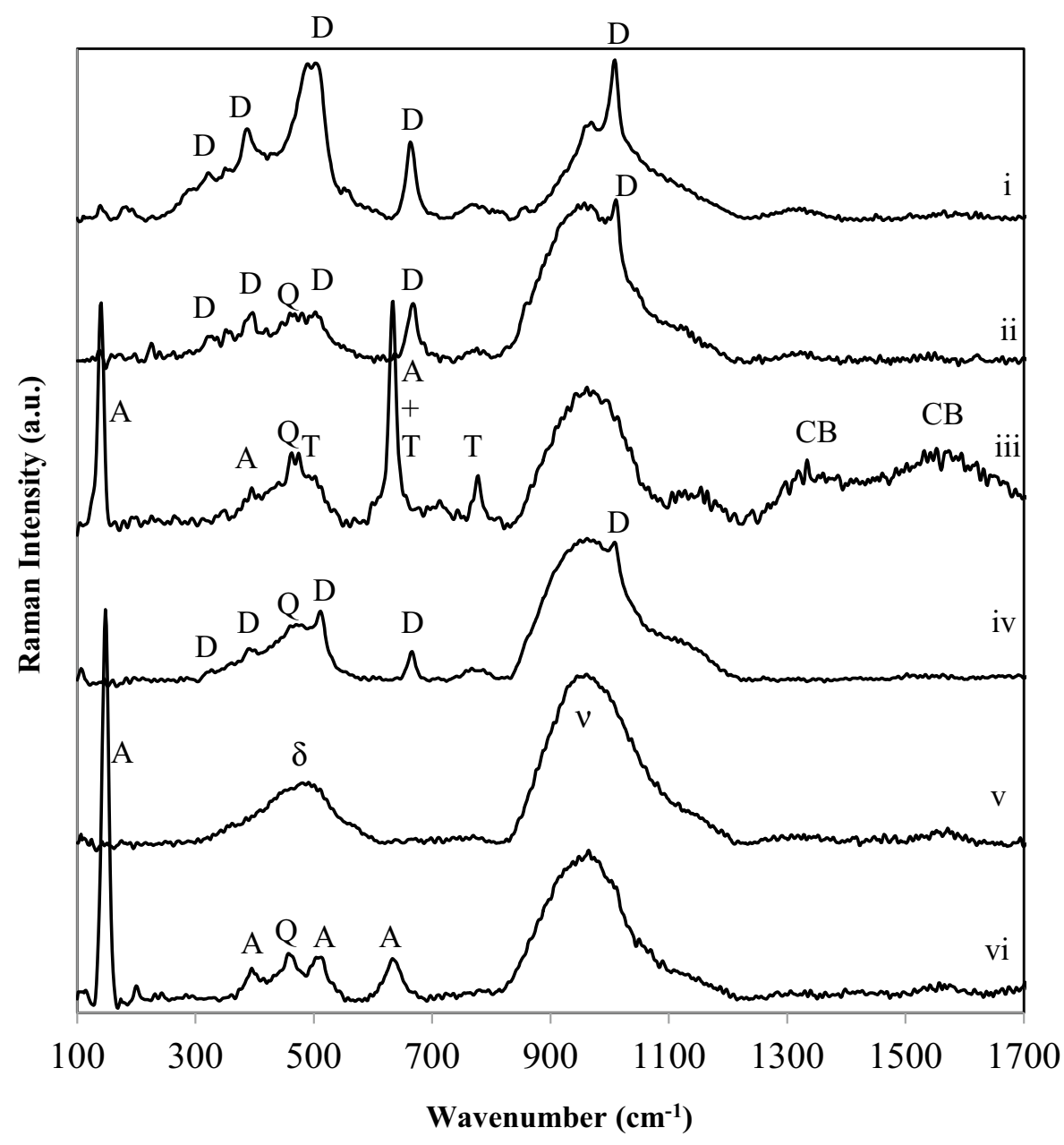

yellow colour could be detected, apart from the Diopside peaks.

The polymerization index is $\sim 0.3$, in the case of dark brown glaze, and even smaller in the dark yellow glaze. This indicates a firing temperature for the glaze in the $600-700{ }^{\circ} \mathrm{C}$ range, much lower than the firing temperature of the ceramic body itself. One can also safely conclude that the ceramics were fired twice.

Curve (iii) of Fig. 5 shows the micro-Raman spectrum for the unique white-glazed sherd studied here (sherd A6): anatase, quartz, tin oxide, and carbon black Raman signatures could clearly be detected in the spectrum. Tin oxide peaks are located at 474,634 , and $778 \mathrm{~cm}^{-1}$. The carbon black bands exhibit maxima at 1334 and $1561 \mathrm{~cm}^{-1}$. Crystalline $\mathrm{SiO}_{2}$ peaks at $462 \mathrm{~cm}^{-1}$ and the stretching band of the glaze has its maxima at $962 \mathrm{~cm}^{-1}$.

Thus, the strong white colour on the inside surface of the bowl was obtained with the use of both tin oxide and anatase.

The yellow part of sample A9 (Fig. 1), where yellow and green glazes were used for decoration of the surface, is presented in curve (iv) of Fig. 5. Superimposed onto the bending and stretching Raman envelopes of the glaze, only Diopside and Quartz $\left(462 \mathrm{~cm}^{-1}\right)$ could be detected. This spectrum was obtained on the surface of the glaze, so it is reasonable to assume that the diopside mineral (and probably small amounts of $\mathrm{Fe}(\mathrm{III})-\mathrm{SO}_{3}$ chromophore) can be considered the pigments responsible for the yellow colour since the antimony level was below the detection limit for XRF.

Curves (v) and (vi) of Fig. 5 refer to the green glaze, (v) obtained on the surface of the sherd A8 and (vi) of sherd A7 at about $40 \mu \mathrm{m}$ deep, using again the confocal capabilities of our micro-Raman setup. Calculating the polymerization index for curve (v) we obtained a kiln temperature $\leq 700{ }^{\circ} \mathrm{C}$ for firing the slip used to form the ceramic glaze. Interestingly, the green glaze of sample A7 exhibits the characteristic peaks of anatase $\left(145,396,505\right.$ and $\left.634 \mathrm{~cm}^{-1}\right)$, used as a whitening substance to improve the visual effect of the green glaze.

Green glazes may be obtained in different ways, namely by dissolution of $\mathrm{Cu}^{2+}$ in the lead-based glaze. In that case, no specific Raman signature can be observed [30, 31], because $\mathrm{Cu}^{2+}$ is dissolved in the matrix. Other ways used 


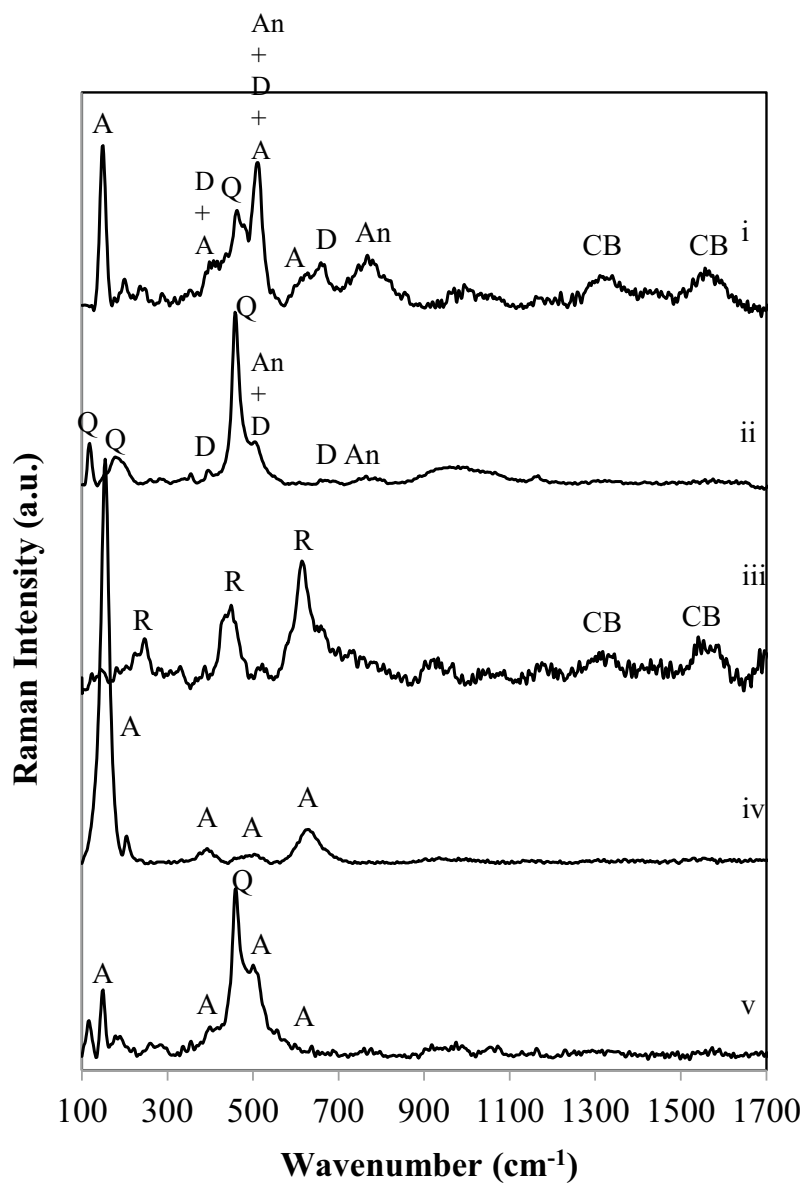

Fig. 6 Micro-Raman spectra obtained for the pastes of Alenquer sherds. The Raman signals are assigned to: quartz (Q), anorthite $(\mathrm{An})$, anatase $(\mathrm{A})$, diopside $(\mathrm{D})$, rutile $(\mathrm{R})$ and carbon black $(\mathrm{CB})$

to obtain the green glaze are to mix yellow and blue pigments (e.g. Naples blue in cobalt containing glaze [33, 34]) or to use chromium-containing pigments [33], among others. For the Alenquer samples $\mathrm{Cu}^{2+}$ is certainly the origin of the green colour, as XRF studies (previously presented) and diffuse reflectance data (to be shown later) would indicate.

The Raman spectra for the green glaze are quite different from those obtained for pottery from the coeval kilns of Santo António da Charneca and Mata da Machada [2, 18]. For these two kilns, most pottery was produced with Pliocene clays, while at Alenquer Jurassic clays were used. The kiln temperature used to form the ceramic glaze, however, was similar, judged by the polymerization indexes detected.

Ceramic bodies It is interesting to note that the Raman spectra of the pastes revealed clear differences in the mineralogical compositions of Groups 1 and 2 of the Alenquer pottery. Curves (i)-(iii) clearly exhibit anorthite, diopside and rutile, minerals which are formed at high kiln temperatures $\left(900-950{ }^{\circ} \mathrm{C}\right)$, clearly the case of the Group 2 pastes. In contrast, in the pastes of Group 1 only quartz and anatase

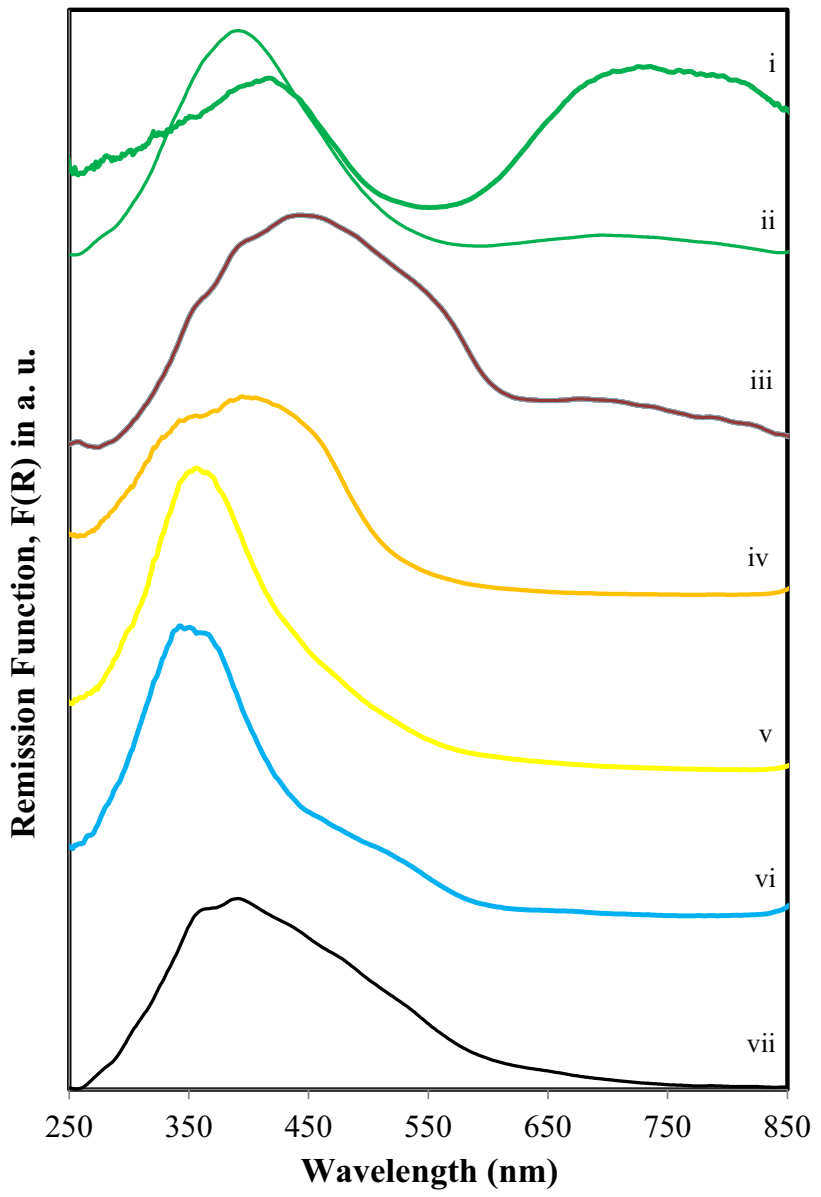

Fig. 7 GSDR absorption spectra of the different coloured glazes of Alenquer sherds: (i) and (ii) green; (iii) dark brown; (iv) dark yellow; (v) yellow; (vi) white; (vii) paste

were identified, as curves (iv) and (v) show. As previously found in the diffractograms of Fig. 3, kaolinite, muscovite and calcite which were detected in the local clays (as collected), totally disappeared in the pastes both for Group 2 and Group 1 after firing at $950{ }^{\circ} \mathrm{C}$ in the laboratory, and are also absent in the Raman spectra of Fig. 6.

\subsection{Ground-state diffuse reflectance absorption studies}

Figure 7 presents some representative GSDR absorption curves for the green-, dark brown-, dark and light yellowand white-coloured glazes, as well as one curve representative of the body.

From the reflectance curves, and by the use of the Kubelka Munk function $F(R)=(1-R)^{2} / 2 R$, the UV-Vis-NIR absorption spectra of the sherds could be obtained for all samples, which are presented in Fig. 7.

The green glaze curves (i) and (ii) are similar to the Santo António da Charneca cases [2,18] with two maxima, one 
in the UV region at about $380 \mathrm{~nm}$, and another in the visible range at about $700 \mathrm{~nm}$. The amount of copper oxide revealed by XRF is significant, pointing to pigments containing copper as the ones responsible for the green glaze in the Alenquer sherds.

The dark brown curve (iii) reveals a broad absorption in the UV/Vis region with shoulders at $\sim 380$ and $435 \mathrm{~nm}$. These shoulders are compatible with the $\mathrm{Fe}^{3+}$ ferric ion absorption [30]. In general, curves (iii) and (iv) for dark brown and dark yellow, respectively, are in agreement with the formation of the $\mathrm{Fe}(\mathrm{III})-\mathrm{SO}_{3}$ charge transfer transition from the ferric ion, directly related to the dark yellow colour [30-32]. Dark yellow glaze absorption curve (iv) exhibits a maxima spreading also in the UV/Vis region, from a maximum at about $420 \mathrm{~nm}$, and also with long tail in the visible region.

The yellow glaze curve (v) essentially reveals a strong absorption in the UV range.

The white glazes of sample 6 (curve (vi)) exhibit a strong absorption band in the UV, compatible with a strong UV absorption of $\mathrm{SnO}_{2}$ in this spectral region.

Curve (vii) was obtained for the Jurassic paste of Alenquer and it is similar to previous ones already studied and published in [15].

\section{Conclusions}

The ceramics from the Alenquer kiln were fired twice, the first time at high temperatures, in the $850-950{ }^{\circ} \mathrm{C}$ range, and the second time at a much lower temperature to obtain the pottery lead-based glaze. In the latter case, temperatures ranged from 600 to $700{ }^{\circ} \mathrm{C}$. These two firing processes are in accordance with the fact that potters only used the silica slip for glazing the pottery when the biscuit was deemed perfect. Rejected ceramics were discarded before initiating the glazing process. This was actually a recurrent method of production for glazed ceramics since it made production more profitable. Lead was among the most expensive raw materials and by firing the objects twice if any imperfections in the production of the vessel led to its breakage it would happen before the objects had been glazed.

The mineralogical study of the ceramic bodies revealed two types of pastes: one where muscovite, quartz, rutile and vestigial amounts of gehlenite and anorthite were detected in the diffractograms, and a second group where muscovite is absent, some diopside and anorthite were formed, especially the latter in most cases. Pastes from Group 1 were converted into Group 2 pastes whenever the kiln temperature was raised from about $850-950{ }^{\circ} \mathrm{C}$, as proved by firing Group 1 pastes which were transformed into Group 2 pastes in laboratory.
XRD results as well as the chemical data of Alenquer's pastes point out to a local supply of the raw materials.

These results were compared with those obtained for coeval ceramics produced in Portugal (fifteenth to sixteenth century) also in the Tagus hydrographic basin, namely Santo António da Charneca and Mata da Machada. Significant differences were detected, both in the body of the ceramics and in the glazes' compositions for dark brown/dark yellow, and green glazes. The dark yellow colour was related to the absorption band at $\sim 410-420 \mathrm{~nm}$ assigned to $\mathrm{Fe}(\mathrm{III})-\mathrm{SO}_{3}$ chromophore. In this sense, it is now possible to clearly distinguish the productions of three of the major production areas in the Tagus Valley and information which will be very useful in future studies to understand the distribution patterns of these three kiln areas not only in the Tagus area but also in a wider regional basis and how production characteristics may have influenced consumer choices.

Acknowledgements Thanks are due to FCT, Portugal, for the funding of projects UID/NAN/50024/2013, M-ERA-MNT/0002/2015, and Pest-OE/CTM/LA0024/2013. Also to Guilherme Cardoso and Luísa Batalha for supplying part of the samples used in this paper. A final reading of the manuscript is acknowledged to Ilda Januário.

\section{References}

1. G. Cardoso, J.J.F. Gomes, S. Rodrigues, L. Batalha, A produção oleira renascentista na bacia hidrográfica do baixo Tejo. Al-Madan II ${ }^{a}$ Série 2, 54-63 (2016)

2. L.F. Vieira Ferreira, D.S. Conceição, D.P. Ferreira, L.F. Santos, T.M. Casimiro, I. Ferreira Machado, Portuguese 16th century tiles from Santo António da Charneca's kiln: a spectroscopic characterization of pigments, glazes and pastes. J. Raman Spectrosc. 45, 838-847 (2014)

3. T. Casimiro, Faiança portuguesa: datação e evolução crono-estilística. Rev. Port. Arqueol. 16, 351-367 (2013)

4. C. Torres, Um forno cerâmico dos séculos XV e XVI na cintura industrial de Lisboa, Colloque Fours de Potiers et Testares Médièvaux en Mediterranée occidentale: Métodes et Resultats, Published by Casa de Velazquez, Archaeologie XIII, Madrid 1990, pp. 131-141

5. L. Barros, L. Batalha, G. Cardoso, A. Gonzalez, A Olaria Renascentista de Santo António da Charneca-Barreiro, in Velhos e Novos Mundos Estudos de Arqueologia Moderna ed. by A. Teixeira, J. Bettencourt (Cham, Lisboa, 2012), pp. 699-710

6. R. Carmona, C. Santos, Olaria da Mata da Machada: Cerâmica dos Séculos XV e XVI (Câmara Municipal do Barreiro, Barreiro, 2005)

7. M.L. Sorensen, C. Evans, T.M. Casimiro, Pottery in Cidade Velha-Cabo Verde, in Velhos e Novos Mundos. Estudos de Arqueologia Moderna, ed. by A. Teixeira, J. Bettencourt (Cham, Lisboa, 2012), pp. 813-820

8. J.M. Teixeira de Carvalho, A Cerâmica Coimbrã no século XVI (Imprensa da Universidade de Coimbra, Coimbra, 1921)

9. A. Mangucci, Olarias de Louça e Azulejo da Freguesia de Santos-o-Velho: dos meados dos séculos XVI aos meados do século XVII. Al-Madan II ${ }^{a}$ Série 65, 155-168 (1996)

10. T.M. Casimiro, Faiança Portuguesa nas ilhas Britânicas (dos finais do Séc XVI aos Inícios do Século XVIII), $\mathrm{PhD}$ thesis, 
Faculdade de Ciências Sociais e Humanas da Universidade Nova de Lisboa, Lisboa, 2010

11. L.F. Vieira Ferreira, I. Ferreira Machado, A.M. Ferraria, T.M. Casimiro, Ph. Colomban, Portuguese tin-glazed earthenware from the 16th century: a spectroscopic characterization of pigments, glazes and pastes. Appl. Surf. Sci. 285P, 144-152 (2013)

12. G. Zbyszewski, Carta Geológica dos Arredores de Lisboa na escala 1/50 000 - notícia explicativa da folha 4-Lisboa (Serviços Geológicos de Portugal, Lisboa, 1963)

13. C. Lepierre, Estudo Chimico e Technologico sobre a Cerâmica Portuguesa Moderna. (Imprensa Nacional, Lisboa, 1899)

14. G. Zbyszewski, Carta Geológica de Portugal na escala 1/50 000notícia explicativa da folha 30-D_Alenquer (Serviços Geológicos de Portugal, Lisboa, 1965)

15. L.F. Vieira Ferreira, T.M. Casimiro, Ph. Colomban, Portuguese tin-glazed earthenware from the 17th century: pigments and glazes characterization. Spectrochim. Acta, Part A 104, 437-444 (2013)

16. L.F. Vieira Ferreira, D.S. Conceição, D.P. Ferreira, L.F. Santos, M.F.C. Pereira, T.M. Casimiro, I. Ferreira, Machado, Portuguese tin-glazed earthenware from the 17th century. Part 2: a spectroscopic characterization of pigments, glazes and pastes of the three main production centres. Spectrochim. Acta Part A 149, 285-294 (2015)

17. L.F. Vieira Ferreira, R. Varela Gomes, M.F.C. Pereira, L.F. Santos, I. Ferreira Machado Islamic ceramics in Portugal found at Silves Castle (8th to 13th c.): an archaeometric characterization. J Archaeol. Sci. Rep. 8, 434-443 (2016)

18. L.F. Vieira Ferreira, A. Gonzalez, M.F.C. Pereira, L.F. Santos, L.F.,T.M. Casimiro, D.P. Ferreira, D.S. Conceição, I. Ferreira Machado, Spectroscopy of 16th century Portuguese tin-glazed earthenware produced in the region of Lisbon. Ceram. Int. 41, 13433-13446 (2015)

19. L.F. Vieira Ferreira, I. Ferreira Machado, M.F.C. Pereira, T.M. Casimiro, Portuguese blue-on-blue $16^{\text {th }}-17$ th c. pottery. Archaeometry (2018). https://doi.org/10.1111/arcm. 12336

20. L.F. Vieira Ferreira, I.L. Ferreira Machado, Surface photochemistry: organic molecules within nanocavities of Calixarenes. Curr. Drug. Discov. Technol. 4, 229-245 (2007)

21. M. Ozçatal, M. Yaygingol, A. Issi, A. Kara, S. Turan, F. Ohyar, S. Pfeiffer Tas, I. Nastova, O. Grupce, B. Minceva-Sukarova, Characterization of lead glazed potteries from Smyrna (Izmir/Turkey) using multiple analytical techniques; part II: body, Ceram. Int. 40, 2153-2160 (2014)

22. I. Garofano, M.D. Robador, J.L. Perez-Rodriguez, J. Castaing, C. Pacheco, A. Durane, Ceramics from the Alcazar Palace in Seville (Spain) dated between the 11th and 15th centuries: compositions, technological features and degradation processes. J. Eur. Ceram. Soc. 35, 4307-4319 (2015)

23. N.Q. Liem, G. Sagon, V.X. Quang, H.V. Tan, P. Colomban, Raman Study of microstructure, composition and processing of ancient Vietnamese (proto)porcelains and celadons (13-16th centuries). J. Raman Spectrosc. 31, 933-942 (2000)

24. P. Colomban, G. Sagon, X. Faurel, Differentiation of antique ceramics from the Raman spectra of their coloured glazes and paintings. J. Raman Spectrosc. 32, 351-360 (2001)
25. G. Simsek, F. Casadio, P. Colomban, L. Bellot-Gurlet, K.T. Faber, G. Zelleke, V. Milande, E. Moinet, On-site identification of early Böttger red stoneware made at Meissen using portable XRF: 1, body analysis. J. Am. Ceram. Soc. 97, 2745-2754 (2014)

26. P. Ballirano, C. De Vito, L. Medeghini, S. Mignardi, V. Ferrini, P. Matthia, D. Bersani, P.P. Lottici, A combined use of optical microscopy, X-ray powder diffraction and micro-Raman spectroscopy for the characterization of ancient ceramic from Ebla (Syria). Ceram. Int. 40, 409-419 (2014)

27. L. Sebastian, A produção oleira de faiança em Portugal (Séculos $X V I-X V I I), \mathrm{PhD}$ thesis, Faculdade de Ciências Sociais e Humanas da Universidade Nova de Lisboa, Lisboa, 2010, pp 335

28. M.S. Walton, M.S. Tite, Production technology of Roman leadglazed pottery and its continuance into late antiquity. Archaeometry 52, 733-759 (2010)

29. J.W.H. Schreurs, R.H. Brill, Iron and related colours in ancient glasses. Archaeometry 26, 199-209 (1984)

30. D. Moncke, M. Papageorgiou, A. Winterstein-Beckmann, N. Zacharias, Roman glasses coloured by dissolved transition metal ions: redox-reactions, optical spectroscopy and ligand field theory. J. Archaeol. Sci. 46, 23-36 (2014)

31. L.C. Prinsloo, Ph Colomban, A Raman spectroscopic study of the Mapungubwe oblates: glass trade beads excavated at an Iron age archaeological site in South Africa. J. Raman Spectrosc. 39, 79-90 (2008)

32. M.M. Morsi, S.I. El-serbiny, K.M. Mohamed, Spectroscopic investigation of amber colour silicate glasses and factors affecting the amber related absorption bands. Spectrochim. Acta Part A 145, 376-383 (2015)

33. Ph Colomban, V. Milande, L. Le Bilhan, On-site Raman analysis of Iznik pottery glazes and pigments. J. Raman Spectrosc. 35, 527-535 (2004)

34. B. Kirmizi, Ph Colomban, B. Quetteb, On-site analysis of Chinese Cloisonné enamels from the fifteenth to the nineteenth centuries. J. Raman Spectrosc. 41, 780-790 (2010)

35. Ph. Colomban, Polymerization degree and Raman identification of ancient glasses used for jewelry, ceramic enamels and mosaics. J. Non Cryst. Solids 322, 180-187 (2003)

36. Ph Colomban, O. Paulsen, Non-destructive determination of the structure and composition of glazes by Raman spectroscopy. J. Am. Ceram. Soc. 88, 390-395 (2005)

37. Ph Colomban, A. Tournié, L. Bellot-Gurlet, Raman identification of glassy silicates used in ceramics, glass and jewellery: a tentative differentiation guide. J. Raman Spectrosc. 37, 841-852 (2006)

38. $\mathrm{Ph}$. Colomban, On site Raman identification and dating of ancient glasses: a review of procedures and tools. J. Cult. Heritage. 9(Suppl.) e55-e60 (2008)

39. Ph. Colomban, Pottery, glass and enamelled artefacts: how to extract information on their manufactory technology, origin and age?, in Analytical archaeometry: selected topics, ed. by H. Howell, P. Vandenabeele (Royal Society of Chemistry, Cambridge, 2012), pp. 247-270 (Chap. 8)

40. RRUFF Project Database, http://rruff.info/. Accessed Feb 2018 